\title{
Calcified gallstone in a 3 year-old boy: a case report
}

\author{
Erik R Barthel', James R Pierce', Osnat Zmora', Susan R Harlan², Sudha Russell ${ }^{3}$ and Cathy Shin ${ }^{\text {1* }}$
}

\begin{abstract}
Background: Gallstones are relatively rare in children. At-risk populations include patients suffering from hemolysis syndromes. Regardless of etiology, these patients usually will present with postprandial abdominal pain, and ultrasonography is the mainstay of diagnosis. However, some gallstones are radiopaque and can be visualized on plain abdominal radiography.

Case presentation: We present the uncommon but classic plain x-ray finding of a calcified gallstone in a 3 year-old Hispanic boy. He was treated with elective laparoscopic cholecystectomy.

Conclusions: Cholelithiasis is rare in children, and calcified stones that will appear on plain abdominal x-rays are even rarer. If symptomatic, cholecystectomy by a pediatric surgeon is the treatment of choice. We discuss some of the recent developments in treatment of this condition in this patient population.
\end{abstract}

\section{Background}

Although not common in children, gallstones are seen with increased incidence in pediatric patients with hematologic disorders [1]. In adults, an increased risk of gallstones is seen with obesity [2]. Given the rising incidence of obesity in children in the United States, it is likely that cholelithiasis will also increase in this population with time [3]. There are relatively sparse reports in the literature of a calcified gallstone in the pediatric population [4].

\section{Case presentation}

An otherwise healthy 3 years and 10 months-old, $99 \mathrm{~cm}$, $14 \mathrm{~kg}$ Hispanic boy presented to our Emergency Department after multiple visits to other facilities during the same week with a chief complaint of abdominal pain. The pain was described as postprandial and crampy, and the child's mother endorsed his aversion to fatty foods and carbonated beverages. She denied emesis, jaundice, icterus, pruritus, or symptoms of altered mental status. Physical examination was unremarkable. Laboratory studies showed only borderline elevated total bilirubin. A plain abdominal $\mathrm{x}$-ray was obtained, which revealed a radiodense mass in the right upper quadrant (Figure 1,

\footnotetext{
* Correspondence: cshin@chla.usc.edu

${ }^{1}$ Division of Pediatric Surgery, Children's Hospital Los Angeles, 4650 Sunset Blvd Mailstop 100, Los Angeles, CA 90027, USA

Full list of author information is available at the end of the article
}

panels A, B, arrows). The patient was diagnosed with calcified gallstone. This was confirmed with an abdominal ultrasound, which further showed that the $1.2 \times$ $0.8 \times 0.7 \mathrm{~cm}$ stone was impacted in the neck of the gallbladder (Figure 1, panels C, D, arrows). Elective cholecystectomy was performed using the standard four-port laparoscopic technique, with the finding of a large pigmented stone in the gallbladder neck.

\section{Discussion}

Fifteen percent of gallstones are sufficiently calcified to be radiodense enough to be visualized on plain radiographs, and of these, two thirds are pigment stones [5]. In general, gallstones are uncommon in children, with patients under 15 comprising only $0.1-0.2 \%$ of the incidence of the disease [6]. In the pediatric population, pigment stones containing bilirubin salts are more common [7]. These types of stones are associated with hemolytic disorders, most commonly sickle cell anemia [8]. In our patient, after his cholecystectomy a hematologic workup was recommended to his primary physician. Laparoscopic cholecystectomy can be safely performed in the case of symptomatic cholelithiasis in this population. It is the treatment of choice for gallstones in children with sickle cell disease [9]. Moreover, it can be safely performed as an outpatient procedure, rather than having to incur the additional costs of an overnight 

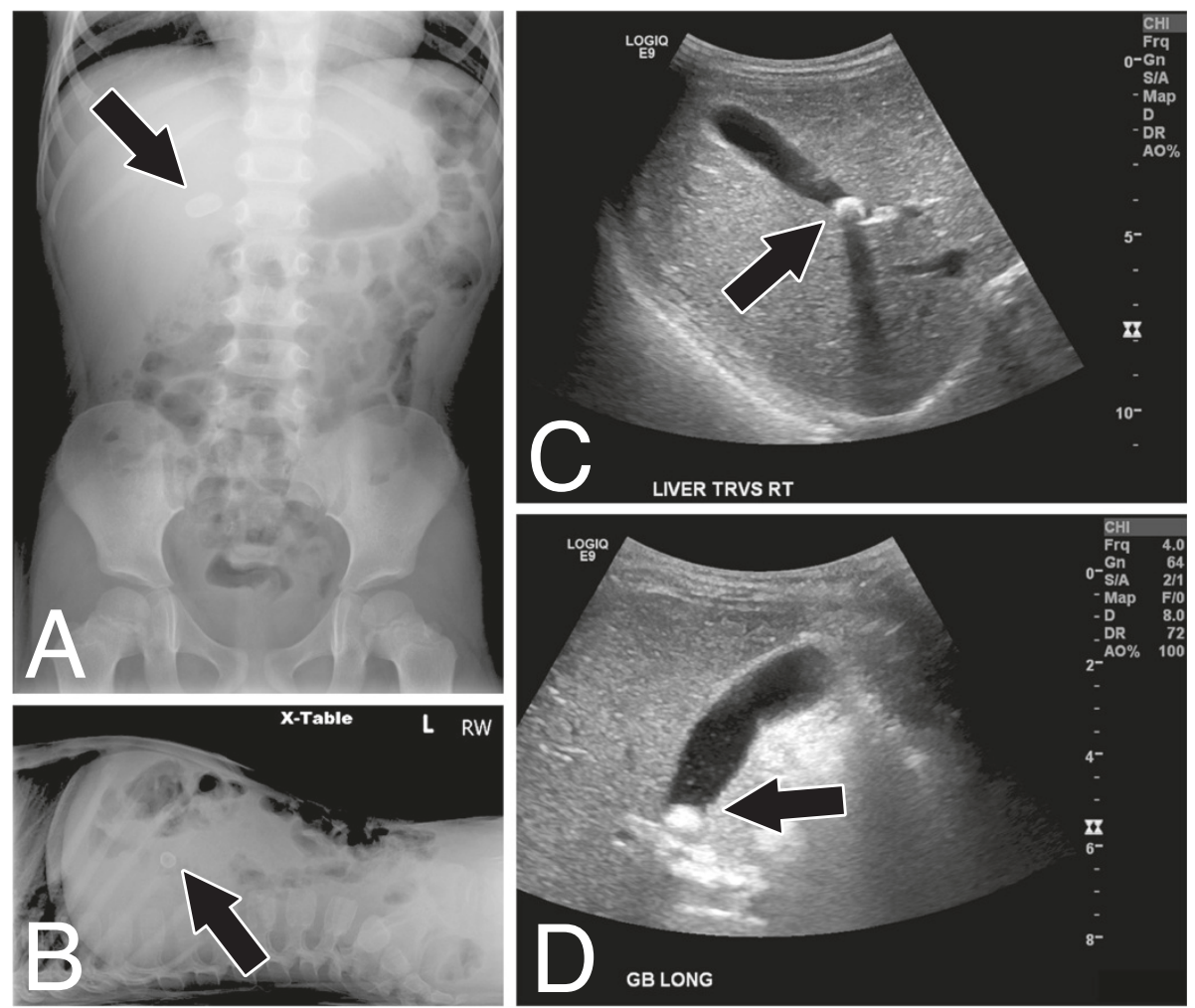

Figure 1 Panel A: anterior/posterior abdominal radiograph. Panel B: Cross-table abdominal radiograph. Panels C, D: Transverse and longitudinal ultrasound views of liver and gallbladder. Arrows indicate the gallstone.

hospital stay [10]. More recently, the use of a singleincision approach, in place of the traditional 4-trocar laparoscopic cholecystectomy employed here, has been applied to pediatric patients. These authors note that the single-incision method can be used in children for a variety of laparoscopic procedures, and though it carries some drawbacks, many of these can be overcome by employing specially adapted instruments [11].

\section{Conclusion}

Despite its relative rarity in comparison to adults, cholelithiasis must always be on the differential diagnosis with a childhood complaint of postprandial abdominal pain. Cholecystectomy is the appropriate treatment for symptomatic cholelithiasis, especially so in children with sickle cell disease or other hemolytic disorders. It can be performed safely in the outpatient setting, and the emerging technique of single-incision laparoscopy will likely play an increasingly important role in its management in carefully selected patients.

\section{Consent}

Written informed consent was obtained from this minor patient's parents for publication of this case report and the accompanying images. A de-identified copy of the written consent is available for review by the Editor-inChief of this journal.

\section{Competing interests}

The authors declare that they have no competing interests.

\section{Authors' contributions}

ERB, JRP and CS performed the literature search and wrote the manuscript. $\mathrm{CS}$ and $\mathrm{OZ}$ performed the surgeries, and SR and SRH provided radiologic images. All authors have read, critically reviewed, and approved the final manuscript.

\section{Acknowledgements}

We thank the Children's Hospital Los Angeles Division of Pediatric Surgery, the Department of Radiology, and the Department of Emergency and Transport Medicine for educational and logistical support. ERB is supported by the California Institute for Regenerative Medicine, grant number TCS-007117.

\section{Author details}

'Division of Pediatric Surgery, Children's Hospital Los Angeles, 4650 Sunset Blvd Mailstop 100, Los Angeles, CA 90027, USA. ²Department of Radiology, Children's Hospital Los Angeles, 4650 Sunset Blvd Mailstop 81, Los Angeles, CA 90027, USA. ${ }^{3}$ Department of Emergency and Transport Medicine,

Children's Hospital Los Angeles, 4650 Sunset Blvd Mailstop 113, Los Angeles, CA 90027, USA.

Received: 21 June 2012 Accepted: 10 August 2012

Published: 13 August 2012

\section{References}

1. Mehta S, Lopez ME, Chumpitazi BP, Mazziotti MV, Brandt ML, Fishman DS: Clinical characteristics and risk factors for symptomatic pediatric gallbladder disease. Pediatrics 2011, 129:e82-e88. 
2. Stinton LM, Myers RP, Shafer EA: Epidemiology of gallstones. Gastroenterol Clin N Am 2010, 39:157-169.

3. Koebnick C, Smith N, Black MH, Porter AH, Richie BA, Hudson S, Gililland D, Jacobsen SJ: Longstreth GF. Pediatric obesity and gallstone disease: results from a cross-sectional study of over 510,000 youth. J Pediatr Gastroenterol Nutr 2012. epub ahead of print.

4. Rudisill $\mathrm{H}$ : X-ray visualization of a calcified gallstone in a child seven years old. Radiology 1931, 16:42-944.

5. Johnston DE, Kaplan MM: Pathogenesis and treatment of gallstones. NEJM 1993, 328:412-421.

6. Punia RPS, Garg S, Bisht B, Dalal U, Mohan H: Clinico-pathological spectrum of gallbladder disease in children. Acta Paediatr 2010, 99:1561-1564.

7. Poddar U: Gallstone disease in children. Indian Peds 2010, 47:945-953.

8. Currò G, Meo A, Ippolito D, Pusiol A, Cucinotta E: Asymptomatic cholelithiasis in children with sickle cell disease: early or delayed cholecystectomy? Ann Surg 2007, 245:126-129.

9. Schinasi DA, Mistry RD: Cholelithiasis in a toddler with sickle cell disease. Pediatr Emerg Care 2011, 27:533-534.

10. Méndez K, Sabater R, Chinea E, Lugo-Vicente H: Is there a safe advantage in performing outpatient laparoscopic cholecystectomy in children? J Pediatr Surg 2007, 42:1333-1336.

11. Hansen EN, Muensterer OJ, Georgeson KE, Harmon CM: Single-incision pediatric endosurgery: lessons learned from our first 224 laparoendoscopic single-site procedures in children. Pediatr Surg Int 2011, 27:643-648.

doi:10.1186/1756-0500-5-433

Cite this article as: Barthel et al:: Calcified gallstone in a 3 year-old boy: a case report. BMC Research Notes 2012 5:433.

\section{Submit your next manuscript to BioMed Central and take full advantage of:}

- Convenient online submission

- Thorough peer review

- No space constraints or color figure charges

- Immediate publication on acceptance

- Inclusion in PubMed, CAS, Scopus and Google Scholar

- Research which is freely available for redistribution 